\title{
Biotransformation enzymes in Cyphoma gibbosum (Gastropoda: Ovulidae): implications for detoxification of gorgonian allelochemicals
}

\author{
Nicholas H. Vrolijk* , Nancy M. Targett \\ University of Delaware Graduate College of Marine Studies, Lewes, Delaware 19958, USA
}

\begin{abstract}
The role of biotransformation enzymes in metabolism of lipophilic, dietary allelochemicals such as terpenoids and steroids has not been studied in marine organisms despite the significance of allelochemicals in the evolution of biotransformation enzymes and the importance of these enzymes in detoxification of anthropogenic xenobiotics. Here we report on cytochrome P450 and glutathione transferase (GST) from the digestive gland of Cyphoma gibbosum, a specialist predator that feeds on allelochemically rich gorgonian corals. Levels of these enzymes were compared from C. gibbosum collected in Belize from 4 different gorgonian prey species (Briareum asbestinum, Gorgonia ventalina, Plexaura homomalla, and Pseudopterogorgia americana). Cytochrome P450 specific content was very low and only quantifiable in C. gibbosum collected from $P$. americana $\left(21.4\right.$ to $\left.27.4 \mathrm{pmol} \mathrm{mg}^{-1}\right)$. A peak at ca $420 \mathrm{~nm}$ was also detected in most samples, indicative of degraded P450 or an independent, functional haemoprotein. Methoxyresorufin O-deethylase (MROD) and ethoxyresorufin $O$-deethylase (EROD) were not detected in C. gibbosum. However, NADPH-cytochrome C (P450) reductase (NCR) was detected in all samples and the specific activity ranged from 23.2 to $67.3 \mathrm{nmol} \mathrm{min}{ }^{-1} \mathrm{mg}^{-1}$ protein. Significantly higher NCR activity was detected in C. gibbosum collected from prostaglandin-rich $P$. homomalla. Glutathione transferase specific activity ranged from 2.76 to $4.05 \mu \mathrm{mol} \mathrm{min}{ }^{-1} \mathrm{mg}^{-1}$, ranking it among the highest ever reported (using 1-chloro-2,4-dinitrobenzene as a model substrate). Significantly higher GST activity was detected in C. gibbosum collected from G. ventalina and B. asbestinum, suggesting that GST activity varies in response to different suites of gorgonian allelochemicals.
\end{abstract}

\section{INTRODUCTION}

The widespread occurrence of chemical defenses in marine organisms has been well established (Hay \& Fenical 1988, Sammarco \& Coll 1988, Paul 1992). Though these defenses limit predation and herbivory by the majority of potential consumer species, some consumer species regularly feed on allelochemically rich organisms. In the terrestrial environment, strategies for dealing with lipophilic plant allelochemicals are classified as behavioral, physiological or biochemical (Brattsten 1988). Of these 3 strategies, the first 2 have been documented in the marine environment (Faulkner \& Ghiselin 1983, Gerhart 1984, Targett et al. 1986). Little is known, however, about the role of allelochemical biotransformation in marine organisms.

- Present address: Center of Marine Biotechnology, University of Maryland, 600 E. Lombard St., Baltimore, Maryland 21202, USA
For example, high levels of glutathione transferase in herbivorous gastropods and chitons have been suggested to be a response to allelochemicals in their macroalgal diets (Lee et al. 1988, Schlenk \& Buhler 1988). Dietary plant allelochemicals have also been included in a list of natural and anthropogenic foreign compounds which are potential substrates for detoxification enzymes (Livingstone 1991). Chemical defense in general is considered to be a major selective force driving the evolution of several P450 gene families (Gonzalez \& Nebert 1990), indicating that an understanding of the role of allelochemical biotransformation and detoxification in marine organisms holds potential significance for understanding patterns of predation and herbivory in the marine environment.

The species we chose to examine is the ovulid gastropod Cyphoma gibbosum. Commonly found throughout the Caribbean, C. gibbosum feeds exclusively on allelochemically rich gorgonian corals 
(Gerhart 1986, Harvell \& Suchanek 1987 Lasker \& Coffroth 1988), Gorgonian corals are abundant and apparent (sensu Feeny 1976) colonial invertebrates which possess relatively high concentrations of lipophilic allelochemicals such as sesquiterpenes, diterpenes, and in some species, prostaglandins (Faulkner 1984). These compounds have been shown to have a range of bioactivities, including antimicrobial activity, cytotoxicity, ichthyodeterrency, or emetic properties. Acute toxicity of allelochemicals has been documented in herbivorous insects (Berenbaum 1978, Berenbaum \& Neal 1985), though the more common effect is reduction in growth or fecundity or as feeding deterrents (Scriber 1981, Berenbaum et al. 1989). In either case, it is advantageous for an organism to metabolize and detoxify these compounds to an excretable product.

Biotransformation enzymes occur in marine organisms, but they have been studied primarily with regard to their role in the metabolism of anthropogenic xenobiotics, e.g. polycyclic aromatic hydrocarbons (PAHs) and polychlorinated biphenyls (PCBs) (reviewed by James 1989, Stegeman 1989, Livingstone 1991). Two of the most important enzyme systems involved in the metabolism of xenobiotics are cytochrome P450s (Guengerich 1991) and glutathione transferases (Clark 1989). These biotransformation enzymes are known to be involved in the metabolism of dietary allelochemicals in terrestrial systems (Gonzalez \& Nebert 1990, Berenbaum 1991) and we propose that these enzymes may play a similar role in marine organisms.

In order to address the potential significance of biotransformation enzymes in a marine organism which feeds on allelochemically rich prey, we examined aspects of phase I (monooxygenation) and phase II (conjugation) metabolism in Cyphoma gibbosum. Specifically, we measured the specific content of cytochrome P450 and the specific activities of methoxyresorufin O-deethylase (MROD), ethoxyresorufin Odeethylase (EROD), NADPH-cytochrome C (P450) reductase (NCR) and glutathione transferase (GST) in C. gibbosum digestive glands. NCR and GST were further characterized in terms of optimal activity parameters and apparent kinetic characteristics. In addition, though $C$. gibbosum is a specialist on gorgonian corals, it feeds on many different gorgonian species (Gerhart 1986, Harvell \& Suchanek 1987, Lasker \& Coffroth 1988, Lasker et al. 1988). We tested the hypothesis that biotransformation enzyme activities are influenced by feeding on different gorgonian species (and thus different suites of allelochemicals) by collecting C. gibbosum from 4 gorgonian species upon which they commonly feed in Belize and characterizing their P450 and GST activities.

\section{MATERIALS AND METHODS}

Sample collection. Cyphoma gibbosum (ca $3 \mathrm{~cm}$ length) were collected from patch reefs in the vicinity of Carrie Bow Cay, Belize, during February and December 1991. Water temperature during both collection periods was 26 to $28^{\circ} \mathrm{C}$. Field sampling was chosen over lab bioassays for this study because of the difficulty in maintaining gorgonians in aquaria for the periods of time necessary to perform feeding experiments. The 4 gorgonian species upon which C. gibbossum most commonly fed were Briareum asbestinum, Gorgonia ventalina, Plexaura homomalla and Pseudopterogorgia americana. Only snails that were sitting on feeding scars were collected. The assumption was made that these individuals were actively feeding or had recently been feeding. These snails were easily distinguished from those not on feeding scars. The residence time of an individual snail on a particular prey species is highly variable, ranging from 1 to $23 \mathrm{~d}$ (Gerhart 1986, Harvell \& Suchanek 1987, Lasker et al. 1988 ), though the majority of stays are $\geq 3 \mathrm{~d}$.

The digestive glands were dissected within 2 to 4 h of collection and pooled according to gorgonian species fed upon. No distinction was made for sex of the individual. Digestive gland tissue was selected for study because of all molluscan tissues it has been shown to have the highest monooxygenase activity (Livingstone \& Farrar 1984, Schlenk \& Buhler 1988). Ten digestive glands were pooled per sample for the February collections. The December collections contained 5 digestive glands per sample, except where noted. Digestive glands were weighed and immediately frozen in liquid nitrogen and transported in a cryogenic dewar to the University of Delaware College of Marine Studies where they were stored at $-70^{\circ} \mathrm{C}$ until subsequent microsome and cytosol preparation.

Preparation of digestive gland microsomal and cytosolic fractions. Microsomes were prepared from pooled digestive glands by a modification of the method described in Brattsten \& Gunderson (1981). Tissues were overlain with ice-cold homogenization buffer $(0.1 \mathrm{M}$ potassium phosphate, $\mathrm{pH} 7.5,1 \mathrm{mM}$ EDTA, $1.15 \% \mathrm{KCl}$ ) and allowed to thaw on ice. All subsequent procedures were carried out at 0 to $4{ }^{\circ} \mathrm{C}$. The tissues were homogenized in a 1:5 tissue weight: buffer volume ratio with a motor-driven PotterElvehjem teflon homogenizer for $30 \mathrm{~s}$. The crude homogenate was centrifuged for $10 \mathrm{~min}$ at $12000 \times \mathrm{g}$ in a Sorvall RC-5 Superspeed centrifuge, filtered through a plug of glass wool to remove lipids, centrifuged a second time for $10 \mathrm{~min}$ at $12000 \times \mathrm{g}$, and then centrifuged for $20 \mathrm{~min}$ at $250000 \times \mathrm{g}$ in a Sorvall RC-60 ultracentrifuge. This centrifugation protocol separated the membrane-bound cytochrome P450 
(microsomal pellet) and the cytosolic glutathione transferase (supernatant).

The microsomal pellet was suspended in microsomal buffer $10.1 \mathrm{M}$ potassium phosphate buffer, $\mathrm{pH} 7.5$, containing $1 \mathrm{mM}$ EDTA and $50 \%$ glycerol) by gentle hand homogenization with minimal ( 2 to $3 \mathrm{ml}$ ) buffer (Brattsten 1987). Protein concentrations were estimated for microsomal and cytosolic proteins by the Pierce Micro BCA protein assay from the method of Smith et al. (1985) with bovine serum albumin (BSA) used as a standard. Samples were diluted to $1 \mathrm{mg} \mathrm{ml}^{-1}$ and then either immediately used in enzyme assays or refrozen at $-70^{\circ} \mathrm{C}$. Samples stored for several months in this manner suffered no apparent loss of enzyme activity. In addition, preliminary experiments indicated no loss of activity was incurred due to freezing of tissue samples prior to homogenization.

Enzyme assays. Cytochrome P450 specific content was determined by the carbon monoxide difference spectrum $\left(\Delta O D_{450-490}\right)$ of sodium dithionite-reduced samples using an extinction coefficient of $91 \mathrm{mM}^{-1} \mathrm{~cm}^{-1}$ (Omura \& Sato 1964). Assays were run at a protein concentration of $1 \mathrm{mg}$ $\mathrm{ml}^{-1}$ and $\mathrm{pH}$ 7.5. Ethoxyresorufin O-deethylase (EROD) activity was spectrophotometrically assayed by the method of Klotz et al. (1984). The reaction mixture contained 0.1 M Tris- $\mathrm{HCl}, \mathrm{pH} 8.0,0.1 \mathrm{M} \mathrm{KCl,} 2 \mu \mathrm{M} 7$ ethoxyresorufin (Molecular Probes Inc., Eugene, OR, USA), and $60 \mu \mathrm{g}$ microsomal protein in a final volume of $0.5 \mathrm{ml}$. Reactions were initiated by the addition of $\mathrm{NADPH}(0.3 \mathrm{mM}$ final concentration) and run for $3 \mathrm{~min}$ at $30^{\circ} \mathrm{C}$. Methoxyresorufin O-demethylase (MROD) activity was assayed by the method of Mayer et al. (1977) as modified by Brattsten et al. (1980). The reaction mixture contained (in a final volume of $3 \mathrm{ml}$ ) $0.05 \mathrm{M}$ potassium phosphate buffer, pH 8.5, $0.154 \mathrm{M} \mathrm{KCl}, 0.125 \mathrm{mM}$ methoxyresorufin in DMSO, and $60 \mu \mathrm{g}$ of microsomal protein. The reaction was initiated by the addition of NADPH (1.5 mM final concentration) and run for $3 \mathrm{~min}$. Spectrophotometric assays were run either on a Cary 210 or an SLM-Aminco DW2000 dual beam spectrophotometer. Fluorometric assays were run on an SLM-Aminco 8000 spectrofluorometer. All assays were run at room temperature $\left(23\right.$ to $24^{\circ} \mathrm{C}$ ) except where noted.

NADPH-cytochrome c ( 4450$)$ reductase (NCR) activity was measured by the method of Masters et al. (1965) as modified by Brattsten et al. (1980). The optimized reaction mixture contained (in a final volume of $1.0 \mathrm{ml}$ ) $0.1 \mathrm{M}$ potassium phosphate buffer, $\mathrm{pH} 8.5,71 \mu \mathrm{M}$ cytochrome $\mathrm{c}$, and $25 \mu \mathrm{g}$ of microsomal protein. The reaction was initiated by the addition of NADPH $(0.6 \mathrm{mM}$ final concentration). Activity was measured as the increase in the absorbance at $550 \mathrm{~nm}$ (extinction coefficient 21 $\mathrm{mM}^{-1} \mathrm{~cm}^{-1}$ ). Reductase activity parameters were optimized for protein concentration, $\mathrm{pH}$, and cytochrome $\mathrm{c}$ concentration.
Glutathione transferase (GST) activity was determined by the method of Habig et al. (1974). The optimized reaction mixture contained (in a final volume of $1.0 \mathrm{ml}$ ) $0.1 \mathrm{M}$ potassium phosphate buffer, $\mathrm{pH} 7.5$, $1 \mathrm{mM}$ 1-chloro-2,4-dinitrobenzene (CDNB), and $1 \mathrm{mM}$ reduced glutathione (GSH). CDNB was solubilized in ethanol and added in a volume that constituted $5 \%$ of the final reaction mixture volume. The reaction was initiated by the addition of $50 \mu \mathrm{g}$ of cytosolic protein. Activity was measured as the increase in absorbance at $340 \mathrm{~nm}$ (extinction coefficient $9.6 \mathrm{mM}^{-1} \mathrm{~cm}^{-1}$ ). GST activity parameters were optimized for protein concentration, $\mathrm{pH}$, and substrate concentrations.

Apparent enzyme kinetic constants, i.e. maximal rates $V$ and half-maximal substrate concentrations $[S]_{0.5}$ or $K_{\mathrm{M}}$, were determined by linear regression analysis of Eadie-Hofstee plots (Segal 1975). Apparent $K_{\mathrm{M}}$ and $V$ were determined in triplicate for NCR with the artifical electron accepter cytochrome $\mathrm{C}$ and for GST with reduced GSH and the model substrate CDNB for each gorgonian prey treatment.

Statistical analysis. Data are presented throughout as the mean $\pm 1 \mathrm{SD}$ with the number of replicates in parentheses. Analysis of variance and the Tukey multiple comparison test was employed to test for significant differences between means using Systat 5.0. Statistical tests were accepted as significant at $p<0.05$.

\section{RESULTS}

Cyphoma gibbosum digestive glands collected in this study ranged in mean weight from $152 \pm 13$ to $183 \pm 27 \mathrm{mg}$ snail ${ }^{-1}$. Significantly larger digestive glands were found in C. gibbosum collected from Plexaura homomalla than in those collected from Gorgonia ventalina (Table 1). Mean total microsomal protein yields from C. gibbosum digestive glands ranged from

Table 1. Cyphoma gibbosum. Digestive gland weight from specimens collected in situ feeding on different gorgonian species. Number of replicates given in parentheses. Data are presented as mean values of replicate samples each consisting of 2, 5, or 10 digestive glands per replicate (see 'Materials and methods' for description) \pm 1 SD. Analysis of variance and the Tukey multiple comparison test was employed to test for significant differences between the means. Different letters signify statistically different means $(p<0.05)$

Gorgonian prey Digestive gland wt (mg)

Briareum asbestinum (9)

Gorgonia ventalina (9)

Plexaura homomalla (9)

Pseudopterogorgia americana (11)
$179 \pm 33 \mathrm{AB}$

$152 \pm 13 B$

$183 \pm 27 \mathrm{~A}$

$156 \pm 19 \mathrm{AB}$ 
$6.8 \pm 1.7$ to $13.3 \pm 0.3 \mathrm{mg} \mathrm{g}^{-1}$ wet wt and significant prey species differences were detected (Table 2). Total mean cytosolic protein yields ranged from $52.6 \pm 4.0$ to $98.5 \pm 9.7 \mathrm{mg} \mathrm{g}^{-1}$ wet wt and significant prey species differences were detected as well (Table 2). The microsomal yields were significantly greater in $C$. gibbosum collected from $P$. homomalla than from Pseudopterogorgia americana during both collection periods. Similarly, the cytosolic yields were significantly greater in $C$. gibbosum from $P$. homomalla than in snails from the other 3 gorgonian species.

Cytochrome P450 was consistently detected in the digestive glands of Cyphoma gibbosum collected from Pseudopterogorgia americana (Fig. 1). The specific content of $\mathrm{P} 450$ in these tissues ranged from $21.4 \pm 7.1$ to $27.4 \pm 9.2 \mathrm{pmol} \mathrm{mg}^{-1}$ protein (Table 3 ). The wavelength of maximum absorbance was $451.4 \pm 1.7 \mathrm{~nm}$. A spectral peak of comparable magnitude at $421.4 \pm 0.8 \mathrm{~nm}$ was also detected, indicating the presence of P420. Cytochrome P450 and P420 were detected in C. gibbosum collected from Gorgonia ventalina and Plexaura homomalla as well, but were not quantifiable because of baseline instability at the very high sensitivity required to record these spectra. Neither P450 nor P420 were detected in C. gibbosum collected from Briareum asbestinum. EROD and MROD activities were not detected in any $C$. gibbosum digestive gland microsomes.

The specific activity of Cyphoma gibbosum NADPH-cytochrome $c$ (P450) reductase ranged from $23.2 \pm 2.1$ to $67.3 \pm 3.1 \mathrm{nmol} \mathrm{min}{ }^{-1} \mathrm{mg}^{-1}$. Characterization of $C$. gibbosum NCR revealed that assay activity was linear up to $50 \mu \mathrm{g}$ microsomal protein per $1 \mathrm{ml}$ reaction volume (Fig. 2a). Activity was linear beyond this protein concentration as well, but the slope was depressed. The $\mathrm{pH}$ optimum for hepatic NCR was 8.5 , though an optimal range of $\mathrm{pH} 8$ to 8.5 was observed (Fig. 2b). Significantly higher levels of reductase activ- ity were found in C. gibbosum collected from Plexaura homomalla than from the other gorgonian species. Significant differences in apparent kinetic parameters $\left(K_{\mathrm{M}}\right.$ and $V$ ) were also determined (Table 4$)$. Cytochrome $\mathrm{c}$ was a significantly poorer substrate for NADPH-cytochrome $c(\mathrm{P} 450)$ reductase in vitro from C. gibbosum collected from Briareum asbestinum (as determined by comparing $V / K_{\mathrm{M}}$ ratios).

Glutathione transferase specific activity in Cyphoma gibbosum digestive glands ranged from $2.76 \pm 0.17$ to $4.05 \pm 0.51 \mu \mathrm{mol} \mathrm{min}{ }^{-1} \mathrm{mg}^{-1}$ protein (Table 3). This level of cytosolic GST activity is among the highest ever reported in molluscan crude tissue preparations (Table 5). Characterization of C. gibbosum GST with the model substrate CDNB revealed that assay activity was linear up to $50 \mathrm{\mu g}$ microsomal protein per $1 \mathrm{ml}$

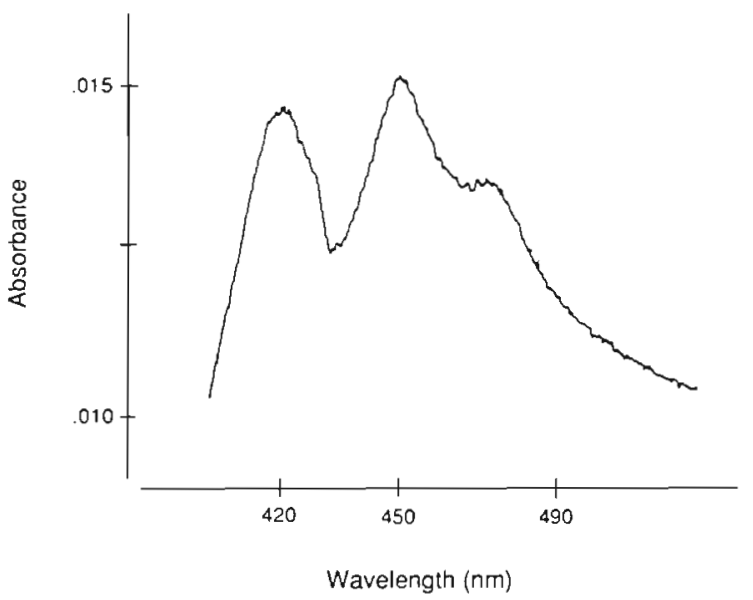

Fig. 1. Cyphoma gibbosum. P450-CO binding spectra of the reduced digestive gland microsomal proteins from specimens collected from $p_{\text {seudopterogorgia americana }}$

Table 2. Cyphoma gibbosum. Quantity of microsomal and cytosolic proteins in digestive glands of specimens collected in situ feeding on different gorgonian prey species. Data are presented as mean values \pm 1 SD with units of $\mathrm{mg}$ protein $\mathrm{g}^{-1}$ wet tissue weight. Number of replicates given in parentheses. Analysis of variance and the Tukey multiple comparison test was employed to test for significant differences between means within each column. Different letters within a column signify statistically different means $(p<0.05)$

\begin{tabular}{|c|c|c|c|c|}
\hline \multirow[t]{2}{*}{ Gorgonian prey } & \multicolumn{2}{|c|}{ February $1991^{\circ}$} & \multicolumn{2}{|c|}{ December $1991^{b}$} \\
\hline & Microsomal protein & Cytosolic protein & Microsomal protein & Cytosolic protein \\
\hline Briareum asbestinum & $10.4 \pm 0.9(5) \mathrm{AB}$ & $72.1 \pm 6.2(5) \mathrm{B}$ & $8.4 \pm 1.0$ (4) $\mathrm{AB}$ & $68.7 \pm 7.4$ (4) B \\
\hline Gorgonia ventalina & $10.8 \pm 2.1(5) \mathrm{AB}$ & $68.0 \pm 2.7(4) \mathrm{B}$ & $11.0 \pm 2.7 \quad(4) \mathrm{A}$ & $59.9 \pm 6.3$ (4) BC \\
\hline Plexaura homomalla & $13.3 \pm 0.3(3) \mathrm{A}$ & $98.5 \pm 9.7$ (3) A & $11.3 \pm 0.7^{c}(4) \mathrm{A}$ & $83.6 \pm 4.5^{\mathrm{C}}(4) \mathrm{A}$ \\
\hline Pseudopterogorgia americana & $8.8 \pm 2.3(5) \mathrm{B}$ & $69.0 \pm 2.1(4) \mathrm{B}$ & $6.8 \pm 1.7 \quad(4) \mathrm{B}$ & $52.6 \pm 4.0$ (4) C \\
\hline \multirow{2}{*}{\multicolumn{5}{|c|}{ Each replicate sample contained 10 digestive glands }} \\
\hline \multicolumn{2}{|c|}{ b Each replicate sample contained 5 digestive glands } & & & \\
\hline \multicolumn{5}{|c|}{ "Each replicate sample contained 2 digestive glands } \\
\hline
\end{tabular}


Table 3. Cyphoma gibbosum. Specific content of microsomal cytochrome P450, specific activity of microsomal NADPHcytochrome $\mathrm{C}(\mathrm{P} 450)$ reductase (NCR) and specific activity of cytosolic glutathione transferase (GST) in digestive glands of specimens collected in February and December 1991 from different gorgonian species. Data are presented as mean values $\pm 1 \mathrm{SD}$. Number of replicates given in parentheses. Analysis of variance and the Tukey multiple comparison test were employed to test for significant differences between means within a column and within each collectıng period. Different letters within a column signify statistically different means $(p<0.05)$

\begin{tabular}{|c|c|c|c|}
\hline Gorgonian prey & 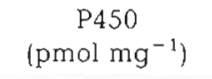 & $\begin{array}{c}\mathrm{NCR} \\
\text { (nmol } \mathrm{min}^{-1} \mathrm{mg}^{-1} \text { ) }\end{array}$ & $\begin{array}{c}\text { GST } \\
\left(\mu \mathrm{mol} \mathrm{min} \mathrm{mg}^{-1} \mathrm{mg}^{-1}\right)\end{array}$ \\
\hline \multicolumn{4}{|l|}{ February } \\
\hline Briareum asbestinum & nd $(7)$ & $23.2 \pm 2.1(7) \mathrm{C}$ & $3.76 \pm 0.21(7) \mathrm{A}$ \\
\hline Gorgonia ventalina & $+(5)$ & $33.4 \pm 2.6(5) B$ & $3.85 \pm 0.39(5) \mathrm{A}$ \\
\hline Plexaura homomalla & $+(6)$ & $67.3 \pm 3.1(6) \mathrm{A}$ & $2.76 \pm 0.17(6) \mathrm{B}$ \\
\hline Pseudopterogorgia americana & $21.4 \pm 7.1(5)$ & $38.8 \pm 5.4(5) \mathrm{B}$ & $2.86 \pm 0.23(5) \mathrm{B}$ \\
\hline \multicolumn{4}{|l|}{ December } \\
\hline Briareum asbestinum & nd (4) & $26.0 \pm 2.0(4) \mathrm{B}$ & $3.43 \pm 0.49(4) \mathrm{AB}$ \\
\hline Gorgonia ventalina & $+(4)$ & $35.6 \pm 6.5(4) \mathrm{B}$ & $4.05 \pm 0.51(4) \mathrm{A}$ \\
\hline Plexaura homomalla & $+(5)$ & $70.0 \pm 11.0(5) \mathrm{A}$ & $3.13 \pm 0.23(4) \mathrm{B}$ \\
\hline Pseudopterogorgia americana & $27.4 \pm 10.6(5)$ & $34.7 \pm 6.0(5) \mathrm{B}$ & $3.43 \pm 0.44(4) \mathrm{AB}$ \\
\hline
\end{tabular}

Table 4. Cyphoma gibbosum. Apparent kinetic constants for NADPH-cytochrome c (P450) reductase in digestive glands from specimens collected in situ feeding on different gorgonian species during February 1991 . The term $V / K_{M}$ indicates the relative affinity the enzyme has for the substrate (cytochrome c). Data are presented as mean values $\pm 1 \mathrm{SD}(\mathrm{n}=3$ ). Analysis of variance and the Tukey multiple comparison test were employed within a column to test for significant differences between the means. Different letters signify statistically different means within a column $(p<0.05)$

\begin{tabular}{|lcccc|}
\hline Gorgonian prey & $\begin{array}{c}\text { Apparent } K_{\mathrm{M}} \\
(\mu \mathrm{mol})\end{array}$ & $\begin{array}{c}\text { Apparent } V \\
\left(\mathrm{nmol} \mathrm{min}-1 \mathrm{mg}^{-1}\right)\end{array}$ & $\mathrm{r}$ & $V / K_{\mathrm{M}}$ \\
\hline Briareum asbestinum (3) & $12.97 \pm 0.24 \mathrm{~A}$ & $26.48 \pm 1.37 \mathrm{~B}$ & 0.87 & $2.04 \pm 0.07 \mathrm{~B}$ \\
Gorgonia ventalina (3) & $4.96 \pm 0.92 \mathrm{C}$ & $31.88 \pm 3.74 \mathrm{~B}$ & 0.90 & $6.74 \pm 0.65 \mathrm{~A}$ \\
Plexaura homomalla (3) & $9.70 \pm 1.06 \mathrm{AB}$ & $70.45 \pm 4.37 \mathrm{~A}$ & 0.94 & $7.35 \pm 1.18 \mathrm{~A}$ \\
Pseudopterogorgia americana (3) & $6.19 \pm 2.70 \mathrm{BC}$ & $31.05 \pm 7.23 \mathrm{~B}$ & 0.83 & $5.47 \pm 2.15 \mathrm{~A}$ \\
\hline
\end{tabular}

Table 5. Compilation of glutathione transferase activity data from molluscan digestive glands. Data represent mean values of activity with CDNB used as a model substrate. All of these organisms were either experimental controls or field-collected samples from areas reported as not contaminated

\begin{tabular}{|c|c|c|c|}
\hline Species & $1^{\circ}$ Food type & GST $\left(\mu \mathrm{mol} \mathrm{min}^{-1} \mathrm{mg}^{-1}\right)$ & Source \\
\hline Cyphoma gibbosum ${ }^{\mathrm{a}}$ & Gorgonians & $2.76-4.05$ & This study \\
\hline Littorina littorea ${ }^{\mathrm{b}}$ & Macroalgae & 0.75 & Lee (1988) \\
\hline Lymnaea stagnalis ${ }^{\mathrm{b}}$ & Plants & 0.35 & Wilbrink et al. (1991) \\
\hline Cerithium floridanum ${ }^{a}$ & Diatoms, detritus & 10.7 & Lee et al. (1988) \\
\hline Nassarius obsoletus & Carrion & 2.9 & Lee et al. (1988) \\
\hline Loligo vulgaris & Fish & 5.5 & Harris et al. (1991) \\
\hline Cryptochiton stelleri & Macroalgae & 1.22 & Schlenk \& Buhler (1988) \\
\hline Sphaerium corneum ${ }^{b}$ & Microalgae & 0.02 & Boryslawskyj et al. (1988) \\
\hline Mytilus edulis ${ }^{b}$ & Microalgae & 0.05 & Lee $(1988)$ \\
\hline
\end{tabular}


reaction volume (Fig. 3a). The $\mathrm{pH}$ optimum for cytosolic GST was 7.5, though an optimal range of 7.5 to 8.5 was observed (Fig. 3b). Differences in GST activity between sampling periods were observed, but the general trends persisted. Significantly higher activity was detected in $C$. gibbosum collected from Gorgonia ventalina than from Plexaura homomalla. Higher GST activity was detected in individuals feeding on Briareum asbestinum, though this difference was only significant in the February collections. No significant differences in apparent $K_{M}$ were observed for either GSH or CDNB, but significant differences in $V$ were observed (Table 6). Both GSH and CDNB were better substrates in vitro for GST from $C$. gibbosum collected from $B$. asbestinum and $G$. ventalina than from $P$. homomalla (as determined by comparing $V / K_{\mathrm{M}}$ ratios).

\section{DISCUSSION}

Biotransformation of dietary allelochemicals in terrestrial systems is well established (Brattsten \& Ahmad 1986, Gonzalez \& Nebert 1990, Berenbaum 1991). In this study we have demonstrated that phase I and phase II biotransformation enzymes are present in Cyphoma gibbosum, a specialist predator of allelochemically rich gorgonian corals, and that enzyme levels can vary with prey species. Cytochrome P450 was detected in very low quantity in most of these gastropods. Neither MROD nor EROD activity was detected in digestive gland microsomes, though NCR activity was present in all samples. Alternatively, high levels of GST activity were detected in the cytosolic fraction of $C$. gibbosum digestive glands. These findings suggest a potentially important role for GST conjugation of dietary allelochemicals in C. gibbosum.

Glutathione transferases are a group of phase II enzymes that catalyze the conjugation of reduced glutathione with a wide range of lipophilic xenobiotics bearing electrophilic sites (Habig et al. 1974). The model substrate CDNB is used in many studies of GST and provides an indication of the combined catalytic activity of all GST isozymes (Clark 1989). In addition to conjugating reactive metabolites formed by P450 oxidative metabolism. GSTs are also induced by dietary allelochemicals in herbivorous insects (Yu 1982, Wadleigh and Yu 1987, Lee 1991). Wadleigh \& Yu (1987, 1988) have further demonstrated metabolism and detoxification of $\alpha, \beta$-unsaturated carbonyl allelochemicals. Given their broad spectrum of catalytic activity and generally high concentration, it is reasonable to conclude that GSTs are important, if not vital, detoxification systems (Jakoby 1978).

The high GST levels reported in Cyphoma gibbosum (2.76 to $4.05 \mu \mathrm{mol} \mathrm{min}^{-1} \mathrm{mg}^{-1}$ ) have also been reported in Papilio polyxenes, a specialist insect herbivore whose larvae feed on toxic, furanocoumarincontaining plants (Lee 1991). High GST activity in other molluscs has also been correlated with feeding on allelochemically defended macroalgae (Lee et al. 1988, Schlenk \& Buhler 1988). GST-catalyzed conjugation of toxic or fitness-reducing dietary electrophilic allelochemicals may be an important detoxification mechanism in some species (Clark 1989). High GST activity has also been reported in several other fieldcollected molluscs. The cephalopod Loligo vulgaris may utilize GST with substrates which arise endogen-

Table 6. Cyphoma gibbosum. Apparent kinetic constants for glutathione transferase in digestive glands from specimens collected in situ feeding on different gorgonian species during February 1991. Substrate concentrations were (a) 0.125 to $2.0 \mathrm{mM}$ GSH and $1.0 \mathrm{mM}$ CDNB and (b) 0.1 to $1.0 \mathrm{mM} \mathrm{CDNB}$ and $1.0 \mathrm{mM} \mathrm{GSH}$. The term $V / K_{\mathrm{M}}$ indicates the relative affinity the enzyme has for the substrate (GSH and CDNB). Data are presented as mean values $\pm 1 \mathrm{SD}(\mathrm{n}=3)$. Analysis of variance and the Tukey multiple comparison test were employed within a column to test for significant differences between the means. Different letters signify statistically different means within a column for each substrate $(p<0.05)$

\begin{tabular}{|c|c|c|c|c|}
\hline Gorgonian prey & $\begin{array}{l}\text { Apparent } K_{\mathrm{M}} \\
\text { (mmol) }\end{array}$ & 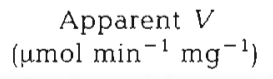 & r & $V / K_{\mathrm{M}}$ \\
\hline \multicolumn{5}{|l|}{ (a) GSH } \\
\hline Briareum asbestinum (4) & $0.36 \pm 0.03 \mathrm{~A}$ & $5.45 \pm 0.44 \mathrm{~A}$ & 0.99 & $15.17 \pm 1.67 \mathrm{~A}$ \\
\hline Gorgonia ventalina (4) & $0.38 \pm 0.05 \mathrm{~A}$ & $5.03 \pm 0.13 \mathrm{~A}$ & 0.99 & $13.60 \pm 2.05 \mathrm{AB}$ \\
\hline Plexaura homomalla (3) & $0.43 \pm 0.05 \mathrm{~A}$ & $3.97 \pm 0.19 \mathrm{~B}$ & 0.99 & $9.33 \pm 1.52 \mathrm{~B}$ \\
\hline Pseudopterogorgia americana (3) & $0.37 \pm 0.02 \mathrm{~A}$ & $3.96 \pm 0.27 \mathrm{~B}$ & 0.98 & $12.02 \pm 2.50 \mathrm{AB}$ \\
\hline \multicolumn{5}{|l|}{ (b) CDNB } \\
\hline Briareum asbestinum (4) & $1.52 \pm 0.25 \mathrm{~A}$ & $9.26 \pm 1.26 \mathrm{~A}$ & 0.96 & $6.15 \pm 0.82 \mathrm{~A}$ \\
\hline Gorgonia ventalina (4) & $1.44 \pm 0.20 \mathrm{~A}$ & $8.36 \pm 0.68 \mathrm{AB}$ & 0.96 & $5.90 \pm 0.77 \mathrm{AB}$ \\
\hline Plexaura homomalla (3) & $1.50 \pm 0.34 \mathrm{~A}$ & $6.36 \pm 0.75 \mathrm{C}$ & 0.98 & $4.30 \pm 0.50 \mathrm{C}$ \\
\hline Pseudopterogorgia americana (3) & $1.51 \pm 0.04 \mathrm{~A}$ & $6.90 \pm 0.46 \mathrm{BC}$ & 0.96 & $4.60 \pm 0.17 \mathrm{BC}$ \\
\hline
\end{tabular}


ously from oxygen toxicity (Harris et al. 1991). Cerithium floridanum and Nassarius obsoletus, 2 infaunal gastropod species, also have high GST activity (Lee et al. 1988). The toxicological or ecological significance of this high activity is presently unknown, but potentially high levels of electrophilic organics in the sediment may serve as substrates for GST (R. F. Lee pers. comm.).

Significant differences in GST activity were detected in Cyphoma gibbosum collected from different gorgonian species. Higher activity was always detected in $C$. gibbosum collected from Gorgonia ventalina. This finding suggests that $C$. gibbosum GST activity varies in response to different suites of gorgonian allelochemicals. Herbivorous insects that feed on different
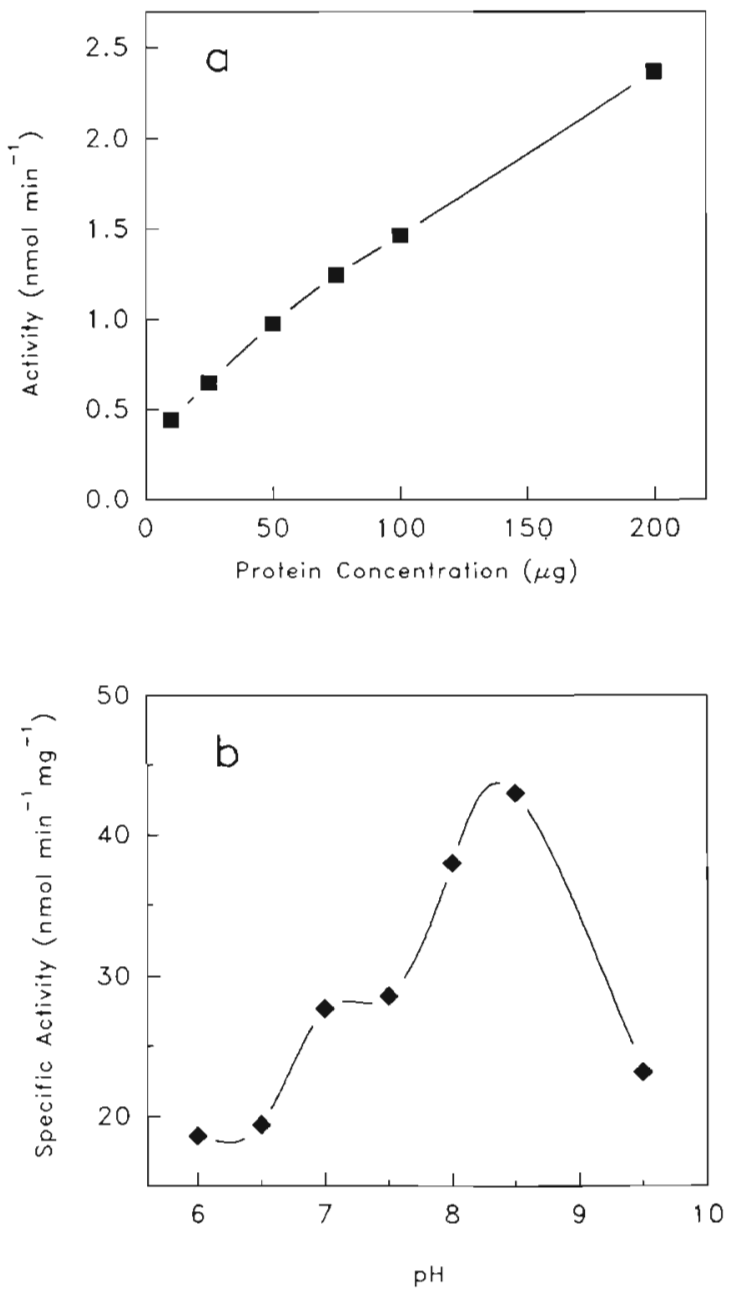

Fig. 2. Cyphoma gibbosum. Effect of (a) protein concentration and (b) pH on NADPH-cytochrome c (P450) reductase activity in specimens collected from Briareum asbestinum. Data are presented as mean value of 3 replicate samples (each run in duplicate)
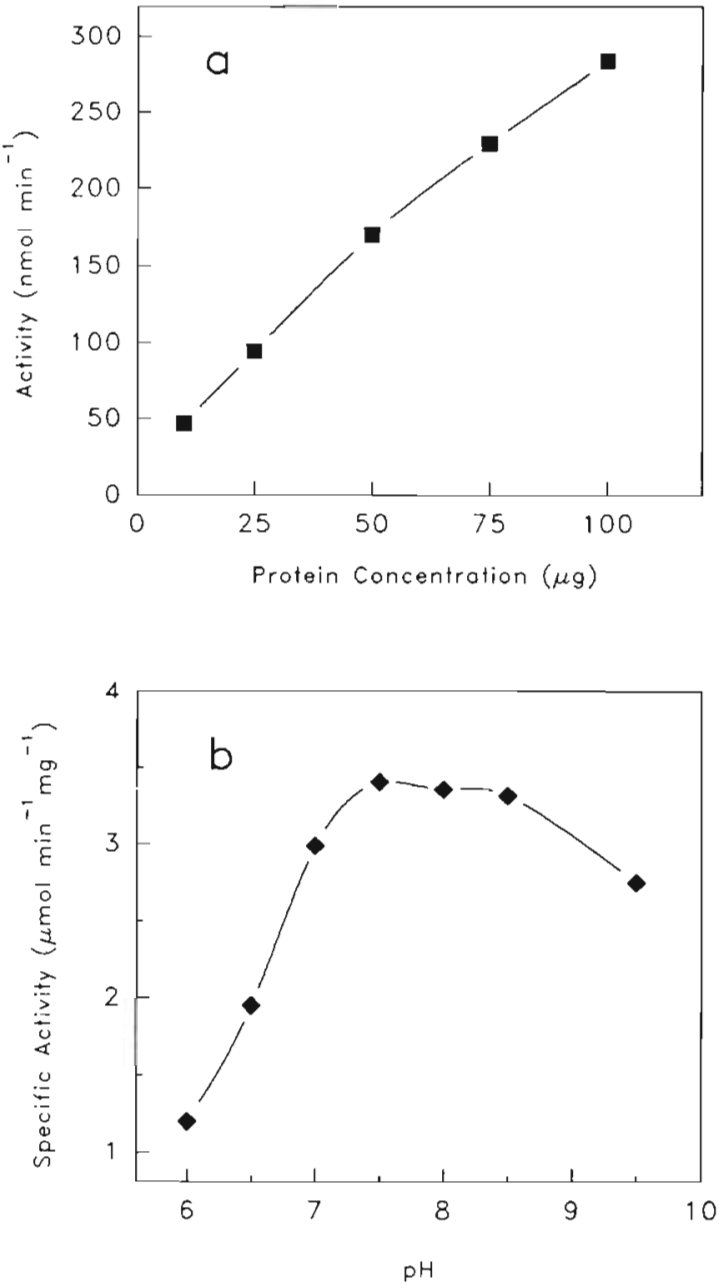

Fig. 3. Cyphoma gibbosum. Effect of (a) protein concentration and (b) $\mathrm{pH}$ on glutathione transferase activity in specimens collected from Briareum asbestinum. Data are presented as mean value of 3 replicate samples (each run in duplicate)

allelochemical-containing plants also have significantly different GST activities (Yu 1982. Ahmad 1983, Rose 1985). The absence of a significant difference in $K_{\mathrm{M}}$ values between $C$. gibbosum collected from different gorgonian prey indicates a quantitative response rather than a qualitative change in GST isozyme content. Probably, either there is a high concentration of the GST isozyme(s) specific for this reaction or the $K_{\mathrm{CAT}}$, a measure of the 'turnover number' that determines the catalytic power of an enzyme, is high and responsible for the higher $V$.

In contrast to high levels of GST, cytochrome P450 was detected at low levels in some Cyphoma gibbosum. The specific content of P450 in C. gibbosum collected from Pseudopterogorgia americana ranged from 21.4 to $27.4 \mathrm{pmol} \mathrm{mg}^{-1}$. This is comparable to the 
amounts of P450 detected in other molluscs (Livingstone 1991). A peak at ca $420 \mathrm{~nm}$ in the CO-difference spectra of dithionite-reduced microsomes was also present, indicative of either the denatured form of P450 or an independent functional haemoprotein, the $418 \mathrm{~nm}$ peak, which appears to be present in many molluscan tissues (Livingstone et al. 1989). This 418-peak has a wider tissue distribution than P450 and it is present in the cytosol (Livingstone \& Farrar 1984). Only trace amounts of $\mathrm{P} 450$ and P420 were detected in C. gibbosum collected from Gorgonia ventalina and Plexaura homomalla. No indication of P450 or P420 was found in C. gibbosum collected from Briareum asbestinum. The inclusion of the protease inhibitors phenylmethylsulfonylfluoride (PMSF) and trypsin inhibitor at final concentrations of $0.2 \mathrm{mM}$ and $20 \mu \mathrm{g} \mathrm{ml}^{-1}$, respectively, had no effect on our ability to quantify total P450, MROD activity or EROD activity.

MROD activity was not detected in Cyphoma gibbosum. The activity of this monooxygenase has not been correlated with a particular P450 form, but $\mathrm{O}$ demethylase activity is induced in herbivorous insects which feed on allelochemical-containing plants (Brattsten pers. comm.). EROD activity was also not detected in Cyphoma gibbosum. This activity is associated with the PAH-inducible P450IA family and has rarely been detected in molluscs (Livingstone et al. 1990). Immunoblot analysis of $C$. gibbosum microsomes with MAb 1-12-3 to scup P450E, the teleost CYP1A1 (Stegeman 1989), indicates that a homologue to scup P450E is not present in C. gibbosum (Vrolijk \& Stegeman unpubl.). Alternatively, $C$. gibbosum may possess a P450IA protein which does not have the epitope recognized by MAb 1-12-3. Microsomes from the digestive gland of the chiton Cryptochiton stelleri were found to react with the polyclonal antibody $\mathrm{LM}_{4 \mathrm{~b}}$, the major $\beta N F$-inducible P450 in trout, demonstrating that some molluscs do possess representatives of the P450IA family (Schlenk \& Buhler 1989).

NADPH-cytochrome $c(\mathrm{P} 450)$ reductase activity was detected in Cyphoma gibbosum digestive glands and the activity was 2 - to 5-fold greater than that reported in other molluscs (Livingstone 1991). This flavoprotein is a key component in electron transfer from NADPH to cytochrome P450 and as such is generally considered an indirect indicator of P450 activity. Increases in NCR and P450 activity in digestive gland microsomes has been observed in gastropods (Thais haemastoma: Livingstone et al. 1986; and Littorina littorea: Livingstone 1988) and bivalves (Moore et al. 1987, Livingstone 1988) as a result of exposure to hydrocarbons. Significantly higher NCR activity was detected in $C$. gibbosum from prostaglandin-rich Plexaura homomalla. Ciereszko \& Schneider (1987) reported biotransformation of the prostaglandin $\mathrm{PGA}_{2}$ to $\mathrm{PGB}_{2}$ in $C$. gibbosum, a reaction potentially catalyzed by $\mathrm{P} 450$. Metabolism of fatty acids, steroids and prostaglandins by P450 is also well established (Schenkman \& Kupfer 1982). These results suggest that there may be P450 forms in C. gibbosum which were not detected. Significant differences in apparent $K_{M}$ between $C$. gibbosum collected from different gorgonian species indicate a change in affinity of the reductase for the model electron accepter, cytochrome c. This change in affinity could be the result of an allelochemical influence on substrate binding to NCR.

Significant differences in the quantity of microsomal and cytosolic proteins $\mathrm{g}^{-1}$ wet wet of digestive gland were detected in samples from both collection periods. Cyphoma gibbosum collected from Plexaura homomalla always had the largest digestive glands and the greatest amount of microsomal and cytosolic protein $\mathrm{g}^{-1}$ digestive gland. In addition, these tissues were distinctively darker in color. Conversely, C. gibbosum collected from Pseudopterogorgia americana had the second smallest digestive glands and the lowest amount of microsomal and cytosolic protein $\mathrm{g}^{-1}$ digestive gland. If digestive gland size is a function of age, i.e. larger individuals are older, then this finding suggests that $C$. gibbosum prey preference may be correlated with age in addition to previously defined factors such as gregariousness, spicule size, food quality, and predator avoidance (Gerhart 1986, Harvell \& Suchanek 1987, Lasker \& Coffroth 1988, Lasker et al. 1988). Hypertrophy, or organ enlargement, in response to pollutants (Fabacher \& Baumann 1985) is unlikely in this instance because the collection site in Belize was pristine.

Preferences displayed by Cyphoma gibbosum are as variable as the study sites at which these preferences have been documented. It is apparent that many biotic and abiotic factors are involved in determining prey preference in C. gibbosum. Significant differences in enzyme activities may reflect differences in allelochemical content of host colonies, but if and how this affects preference is not clear. Cyphoma gibbosum does have high levels of GST, a mechanism which may be a constitutive response to gorgonian allelochemicals in its diet. Utilizing GST conjugation as the primary biotransformation mechanism, rather than $\mathrm{P} 450$ monooxygenation, has the potential benefit of minimizing the production of epoxides and other toxic intermediates. Understanding how organisms deal with potentially toxic or fitness-reducing allelochemicals has significance for understanding patterns of predation and herbivory in the marine environment. It also has implications for environmental toxicology and the potentially confounding effect of dietary allelochemicals on the use of biotransformation enzymes as environmental biomonitors. 
Acknowledgements. We thank L. B. Brattsten for helpful discussions and assistance throughout much of this research, $F$ Bayer for taxonomic verification, and $\mathrm{L}$. B. Brattsten and D. J. Gerhart for reviewing the manuscript. MAb 1-12-3 was a gracious gift of J. J. Stegeman. This research was sponsored in part by the Office of Naval Research (\#N00014-88-K-0290 and \#N0001489-J-3098 to N.M.T.). This publication is contribution No. 359 to the Caribbean Coral Ecosystems Program of the Smithsonian Institution which is partly supported by a grant from the Exxon Corporation.

\section{LITERATURE CITED}

Ahmad, S. (1983). Mixed-function oxidase activity in a generalist herbivore in relation to its biology, food plants, and feeding history. Ecology 64: 235-243

Berenbaum, M. R. (1978). Toxicity of a furanocoumarin to armyworms: a case of biosynthetic escape from insect herbivores. Science 201: 532-534

Berenbaum, M. R. (1991). Comparative processing of allelochemicals in the Papilionidae (Lepidoptera). Arch. Insect Biochem. Physiol. 17: 213-221

Berenbaum, M. R., Neal, J. J. (1985). Synergism between myristicin and xanthothoxin, a naturally co-occurring plant toxicant. J. chem. Ecol. 11: 1349-1358

Berenbaum, M. R., Zangerl, A. R., Lee, K. (1989). Chemical barriers to adaptation by a specialist herbivare. Oecologia 80: 501-506

Boryslawakyj, M. A. C., Garrood, A. C., Pearson, J. T (1988) Elevation of glutathione transferase activity as a stress response to organochlorine compounds, in the freshwater mussel, Sphaerium corneum. Mar. environ. Res. 24: 101-104

Brattsten, L. B. (1988). Enzymatic adaptations in leaf-feeding insects to host-plant allelochemicals. J. chem. Ecol. 14: 1919-1939

Brattsten, L. B., Ahmad S. (1986). Molecular aspects of insectplant interactions. Plenum Press, New York

Brattsten, L. B., Gunderson, C. A. (1981). Isolation of insect microsomal oxidases by rapid centrifugation. Pestic. Biochem. Physiol. 16: 187-198

Brattsten, L. B., Price, S. L., Gunderson, C. A. (1980). Microsomal oxidases in midgut and fatbody tissues of a broadly herbivorous insect larva, Spodoptera erdania Cramer (Noctuidae). Comp. Biochem. Physiol. 66C: 231-237

Ciereszko, L. S., Schneider, W. P. (1987). Conversion of the prostaglandin (15S)-PGA $\mathrm{PA}_{2}$ to (15S)-PGB $\mathrm{PB}_{2}$ in the flamingo gongue snail Cyphoma gibbosum (L.) feeding on the gorgonian Plexaura homomalla (Esper). Bull. mar. Sci. 41: 634

Clark, A. G. (1989). The comparative enzymology of the glutathione S-transferases from non-vertebrate organisms. Comp. Biochem. Physiol. 92B: 419-446

Fabacher, D. I., Baumann, P. C. (1985). Enlarged livers and hepatic microsomal mixed-function oxidase components in tumor-bearing brown bullheads from a chemically contaminated river. Environ. Toxicol. Chem. 4: 703-710

Faulkner, D. J. (1984). Marine natural products: metabolites of marine invertebrates. Nat. Product Rep. 1: 551-598

Faulkner, D. J., Ghiselin، M. T (1983). Chemical defense and evolutionary ecology of dorid nudibranchs and some other opisthobranch gastropods. Mar Ecol. Prog. Ser. 13: 295-301

Feeny, P. (1976). Plant apparency and chemical defense. In: Wallace, J. W., Mansell, R. L. (eds.) Recent advances in phytochemistry, Vol. 10. Plenum Press, New York, p. 1-40
Gerhart, D. J. (1984). Prostaglandin $\mathrm{A}_{2}$ : an agent of chemical defense in the Caribbean gorgonian Plexaura homomalla. Mar Ecol. Prog. Ser. 19: 181-187

Gerhart, D. J. (1986). Gregariousness in the gorgonian-eating gastropod Cyphoma gibbosum. tests of several possible causes. Mar Ecol. Prog. Ser 31: 255-263

Gonzalez, F. J., Nebert, D. W. (1990). Evolution of the P450 gene superfamily: animal-plant 'warfare', molecular drive and human genetic differences in drug oxidation. Trends Genet. 6: 182-187

Guengerich, F. P. (1991). Reactions and significance of cytochrome P-450 enzymes. J. biol. Chem. 266: 10019-10022

Habig, W. H., Pabst, M. J., Jakoby, W B. (1974). Glutathione transferases. The first enzymatic step in mercapturic acid formation. J. biol. Chem. 249: 7130-7139

Harris, J., Coles, B., Meyer, D. J., Ketterer, B. (1991). The isolation and characterization of the major glutathione $\mathrm{S}$ transferase from the squid Loligo vulgaris. Comp. Biochem. Physiol, 98B: 511-515

Harvell, C. D., Suchanek, T H. (1987). Partial predation on tropical gorgonians by Cyphoma gibbosum (Gastropoda). Mar. Ecol. Prog. Ser. 38: 37-44

Hay, M. E., Fenical, W. (1988). Marine plant-herbivore interactions: the ecology of chemical defense. A. Rev. Ecol. Syst. 19: 111-145

Jakoby, W. B. (1978). The glutathione S-transferases: a group of multifunctional detoxification proteins. Adv. Enzymol. relat. Areas Mol. Biol. 46: 383-414

James, M. O. (1989). Cytochrome P450 monooxygenases in crustaceans. Xenobiotica 19: 1063-1076

Klotz, A. V., Stegeman, J. J., Walsh, C. (1984). An alternative 7 -ethoxyresorufin $O$-deethylase activity assay: a continous visible spectorphotometric method for measurement of cytochrome P-450 monooxygenase activity. Analyt. Biochem. 140: 138-145

Lasker, H. R., Coffroth, M. A. (1988). Temporal and spatial variability among grazers: variability in the distribution of the gastropod Cyphoma gibbosum on octocorals. Mar. Ecol. Prog. Ser, 43: 285-295

Lasker, H. R., Coffroth, M. A, Fitzgerald, L. M. (1988). Foraging patterns of Cyphoma gibbosum on octocorals: the roles of host choice and feeding preference. Biol. Bull. 174: $254-266$

Lee, K. (1991). Glutathione S-transferase activities in phytophagous insects: induction and inhibition by plant phototoxins and phenols. Insect Biochem. 21: 353-361

Lee, R. F. (1988). Possible linkages between mixed function oxygenase systems, steroid metabolism, reproduction, molting, and pollution in aquatic animals. Adv. Environ. Sci. Technol. 21: 201-213

Lee, R. F., Keeran, W S., Pickwell, G. V (1988). Marine invertebrate glutathione transferases: purification, characterization and induction. Mar. environ. Res. 24: 97-100

Livingstone, D. R. (1988). Responses of microsomal NADPHcytochrome c reductase activity and cytochrome P-450 in digestive glands of Mytilus edulis and Littorina littorea to environmental and experimental exposure to pollutants. Mar Ecol. Prog. Ser. 46: 37-43

Livingstone, D. R. (1991). Organic xenobiotic metabolism in marine invertebrates. Adv. comp. environ. Physiol. 7: 46-185

Livingstone, D. R., Farrar, S. V (1984). Tissue and subcellular distribution of enzyme activites of mixed function oxygenase and benzola|pyrene metabolism in the common mussel Mytilus edulis L. Sci. total Environ. 39: 209-235

Livingstone, D. R., Stickle, W. B., Kapper, M., Wang, S. (1986). Microsomal detoxification enzyme responses of the marine 
snail, Thais haemastoma, to laboratory oil exposure. Bull environ. Contam. Toxicol. 36: 843-850

Livingstone, D. R., Kirchin, M. A., Wiseman, A. (1989). Cytochrome P.450 and oxidative metabolism in molluscs. Xenobiotica 19: 1041-1062

Livingstone, D. R., Arnold, R., Chipman, K., Kirchin, M. A., Marsh, J. (1990). The mixed-function oxygenase system in molluscs: metabolism, responses to xenobiotics and toxicity. Oceanis 16: 331-347

Masters, B. S., Kamin, H., Gibson, Q. H., Williams, C. H. Jr (1965). Studies on the mechanism of microsomal triphosphopyridine nucleotide-cytochrome c reductase. J. biol. Chem. 240: 921-931

Mayer, R. T., Jermyn, J. W., Burke, M. D., Prough, R. A. (1977) Methoxyresorufin as a substrate for the fluorometric assay of insect microsomal dealkylases. Pestic. Biochem. Physiol. 7: $349-354$

Moore, M. N., Livingstone, D. R., Widdows, J., Lowe, D. M., Pipe, R. K. (1987). Molecular, cellular, and physiological effects of oil-derived hydrocarbons on molluscs and their use in impact assessment. Phil. Trans. R. Soc. Lond. 316 $603-623$

Omura, T., Sato, R. (1964). The carbon monoxide-binding pigment of liver microsomes. I. Evidence for its hemoprotein nature. J. biol. Chem. 239: 2370-2378

Paul, V. J. (1992). Ecological roles of marine natural products. Comstock Publishing Associates, Ithaca

Rose, H. A. (1985). The relationship between feeding specialization and host plants to aldrin epoxidase activities of midgut homogenates in larval Lepidoptera. Ecol. Entomol. 10: $455-467$

Sammarco, P. W., Coll, J. C. (1988). The chemical ecology of alcyonarian corals. In: Scheuer, P. J. (ed.) Bioorganic marine chemistry, Vol. 2. Springer-Verlag, Berlin, $p$. $87-116$

Schenkman, J. B., Kupfer, D. (1982). Hepatic cytochrome P450 monooxygenase system. Pergamon Press, Oxford

Schlenk, D., Buhler, D. R. (1988). Cytochrome P-450 and

This manuscript was submitted to the editor phase II activities in the gumboot chiton Cryptochiton stelleri. Aquat. Toxicol. 13: 167-182

Schlenk, D., Buhler, D. R. (1989). Determination of multiple forms of cytochrome P-450 in microsomes from the digestive gland of Cryptochiton stelleri. Biochem. biophys. Res. Commun. 163: 475-480

Scriber, J. M. (1981). Sequential diets, metabolic costs, and growth of Spodoptera eridania (Lepidoptera: Noctuidae) feeding upon dill, lima bean, and cabbage. Oecologia 51: $175-180$

Segal, I. H. (1975). Biochemical calculations, 2nd edn. John Wiley and Sons, New York

Smith, P. K., Krohn, R. I, Hermanson, G. T., Mallia, A. K., Gartner, F. H., Provenzano, M. D.,Fujimoto, E. K., Goeke, N. M., Olson, B. J., Klenk, D. C. (1985). Measurement of protein using bicinchoninic acid. Analyt. Biochem. 150: $76-85$

Stegeman, J. J. (1989). Cytochrome P-450 forms in fish: catalytic, immunological and sequence similarities. Xenobiotica 19: $1093-11.10$

Targett, N. M., Targett, T. E., Vrolijk, N. H., Ogden, J. C. (1986). The effect of macrophyte secondary metabolites on feeding preference of the herbivorous parrotfish Sparisoma radians. Mar. Biol. 92: 141-148

Wadleigh, R. W., Yu, S. J. (1987). Glutathione transferase activity of fall armyworm larvae toward $\alpha$, $\beta$-unsaturated carbonyl allelochemicals and its induction by allelochemicals. Insect Biochem. 17: 759-764

Wadleigh, R. W., Yu, S. J. (1988). Detoxification of isocyanate allelochemicals by glutathione transferase in three lepidopterous species. J. chem. Ecol. 14: 1279-1288

Wilbrink, M. van de Merbel, N. C., Vermeulen, N. P. E. (1991). Glutathione S-transferase activity in the digestive gland of the pond snail, Lymnaea stagnalis. Comp. Biochem. Physiol. 99C: 185-189

Yu, S. J. (1982). Host plant induction of glutathione S-transferase in the fall armyworm. Pestic. Biochem. Physiol. 17. 101

Manuscript first received: July 7, 1992

Revised version accepted: September 29, 1992 